\title{
Effects of rooftop solar on housing prices in Australia
}

\section{CCEP Working Paper 2105 Apr 2021}

\section{Rohan Best}

Department of Economics, Macquarie University

\section{Paul J. Burke}

Crawford School of Public Policy, Australian National University

\section{Rabindra Nepal}

School of Business, Faculty of Business and Law, University of Wollongong

\section{Zac Reynolds}

Department of Economics, Macquarie University

\begin{abstract}
Hedonic models of housing prices face the risk of omitted variable bias due to the challenge of controlling for all relevant property attributes. The level of household financial assets is a key but underexplored control that may help to account for some of these difficult-to-observe property characteristics. Using large Australian household surveys, we find that controlling for household financial assets reduces the observed effect of having solar photovoltaic panels on housing prices. The elasticity of housing price with respect to solar capacity is 0.09 for households with solar panels. Controlling for financial assets may be of use in other studies seeking to estimate the effect of home additions on housing prices.
\end{abstract}




\section{Keywords:}

financial assets; hedonic pricing; housing; location; solar

\section{JEL classification:}

D10; D14; Q40; R21; R30

\section{Suggested citation:}

Best, R., Burke, P.J., Nepal, R. and Reynolds, Z. (2021), Effects of rooftop solar on housing prices in Australia, Working Paper 2105, Apr 2021, Centre for Climate and Energy Policy, Crawford School of Public Policy, The Australian National University.

\section{Address for correspondence:}

Rohan Best, Department of Economics, Macquarie University, NSW 2109, Australia.

The Centre for Climate Economics and Policy is a research unit at the Crawford School of Public Policy at the Australian National University. The working paper series is intended to facilitate academic and policy discussion. The views expressed in working papers are those of the authors. 


\section{Introduction}

Which housing attributes contribute substantially to housing prices? The main search screen of online real estate websites typically displays the location, number of rooms, and the housing type (house/townhouse/unit) for each property. The list of other relevant attributes is likely to be long. Researchers face a challenge when estimating hedonic housing price models as many housing characteristics are not included in available datasets, introducing potential sources of omitted variable bias. In this paper we investigate this issue for the case of solar photovoltaic panel installations in Australia.

There are multiple benefits from having rooftop solar. Solar panels provide households with access to self-generated electricity and feed-in tariff revenue, which help to reduce electricity bills. It is estimated that Australian households with a solar photovoltaic (PV) system on average save $\mathrm{A} \$ 538$ on electricity bills per year compared to non-solar households (ACCC 2018). This in turn contributes to a substantial reduction in energy-related financial stress (Best and Burke 2019). Other benefits include contributing to emissions reductions and the "warm glow" feeling from taking environmentally-friendly actions (Andreoni 1990; Ma and Burton 2016). Some solar panel installations also look good and thereby improve the aesthetic value of the property, although this is not always the case.

In Australia, small-scale residential solar systems are typically not removed from rooftops at the time of sale, instead being transferred as an asset to the new owner. From a theoretical point of view, the installation of solar PV panels should thus be expected to increase a home's sales value by the present value of the future net benefits provided by the solar panels, provided that the market is adequately informed and makes accurate calculations. Note that portable micro solar PV systems such as for outside lights are not measured in the surveys and are not included among the solar systems being analysed.

The effect of solar installations on housing prices is of interest to both market participants and policymakers. Homeowners may be interested in their ability to capitalise the investment into their home's sale price. Of interest to policymakers is that a positive effect means that solar PV promotion policies would carry inequality implications that get passed along in the form of higher housing prices. Higher housing prices due to solar installations would make it even harder for first home buyers to enter the market. If these installations have been incentivised by solar subsidies or other policies, this would be of public policy concern. 
Australia is a global frontrunner in the installation of solar PV, with its high insolation rates being well suited to the technology (Zander et al. 2019). Indeed, Australia has the highest per capita installation level of solar PV in the world (644 watts as of the end of 2019) (IEA, 2020). The rooftop installation rate is particularly high, with more than one in five dwellings having rooftop PV in all states and territories other than Tasmania as of September 2020 (APVI, 2020). One particular characteristic of the Australian context is that the premium feed-in tariffs made available in early years typically expire on transfer of property ownership. For these homes, part of the benefit of solar PV installation would thus not be expected to flow through to a housing price premium. However many households have installed solar panels in the period since the discontinuation of the early feed-in tariff schemes.

The main methodological contribution in this paper is the introduction of a household financial asset control in hedonic regressions. The rationale for doing so is that financial assets reflect households' underlying abilities to invest in home improvements and amenity, and are thus likely to be correlated with various difficult-to-observe property attributes. Controlling for financial assets thus has the potential to reduce the size of potential omitted variable bias. Other socioeconomic characteristics, such as income, may be less effective at doing so given that assets are a more fundamental measure of a household's ability to invest (being an accumulated stock rather than a flow). The results suggest that a financial asset variable appears to be a highly useful control when estimating the effect of home improvements on housing values. We also use a component of financial assets, the private pension balance, in some regressions.

Several measures of household solar panel installations are used in the study. The first is a binary variable for solar PV uptake. The second is a binary variable for solar PV systems larger than 3.5 kilowatts, the average household system size across two Australian surveys (ABS 2017; 2019). We also use a 2.5 kilowatt cut-off in some regressions. The paper also uses log solar capacity and the inverse hyperbolic sine (IHS) transformation of solar capacity. We control for the lagged local-median housing price for both stand-alone houses and attached dwellings to help to separate the impact of solar panels from location effects. 


\section{Prior studies}

\subsection{Energy effects on housing values}

There has been wide interest in the link between energy-related investments and housingsector outcomes. Holtermans and Kok (2019) found that higher rents can be charged for office buildings that have green certification. Green office buildings have been found to receive a price premium of about $16 \%$ in the US (Eichholtz et al. 2010). Zhang et al. (2020) found that green hotels can charge around $6.5 \%$ more for rooms without a reduction in occupancy rates. Chegut et al. (2020) analysed professional appraisals of rental housing, finding that energy efficiency has become important for valuations in more recent periods.

There is a well-developed literature on the willingness to pay for energy-efficient homes by homeowners. It has been found that "green" (energy efficient) homes attract a price premium of approximately 4\% in countries such as the US or Singapore (Brounen and Kok 2011; Deng et al. 2012; Kahn and Kok 2014). Walls et al. (2017) examined the housing price premium associated with Energy Star and green certification for homeowners in three U.S. metropolitan areas. They found that Energy Star certificates on average increase the sale price of homes by about $2 \%$. Green home certification was found to be even more valuable, on average adding approximately $4 \%$ to housing prices. Yoshida and Sugiura (2015) analysed multiple green factors and their effects on condominium prices. Shen et al. (2020) found that dwellings with an air source heat pump attracted a house price premium of up to $7 \%$ in the United States.

Prior studies have found a range of results on the effects of solar panels. Using housing data for San Diego, Sacramento, and California, Dastrup et al. (2012) found that solar PV systems add approximately $3.5 \%$ to the sale price of a house. Hoen et al. (2013) found a similar premium in California, but also that the PV premium seems to be smaller for new homes. In Arizona, a housing price premium of around 15\% has been found for solar panels (Qiu et al. 2017). The exact magnitude of the effect should be expected to be a function of the level of housing prices, the retail price of electricity, and other factors such as the solar feed-in tariff.

There are three studies looking at the effect of binary measures of having solar panels on housing prices in Australia. Ma et al. (2016) found premia at the time of sale of $2-3 \%$ in Western Australia using hedonic methods and a repeat-sales model. They concluded that the cost of installing solar PV systems is fully recouped by the homeowner through the higher 
housing price. Fuerst and Warren-Myers (2018) found an insignificant effect in the Australian Capital Territory. Lan et al. (2020) found a solar PV premium of around 4\% for house prices in southern Queensland. Ours is the first to study the Australian market more broadly and to focus on impacts related to the size of solar systems.

\subsection{Estimation approaches}

A typical approach to the estimation of attribute values is to use a hedonic pricing function (Abelson et al. 2013; Dastrup et al. 2012; Kahn and Kok 2014; Ma et al. 2016; Qiu et al. 2017; Walls et al. 2017). This involves regressing the sale price of a home on a set of structural and environmental characteristics. A challenge is to incorporate sufficient explanatory variables to reduce the likelihood of omitted variable bias. The effects of solar panels might otherwise be confounded with the effects of other home attributes such as energy efficiency investments or the quality of home maintenance.

Locational effects are also relevant to consider: the sale price of a home is likely to be highly correlated with the sale prices of nearby homes (Wilhelmsson 2000). Such effects can be accounted for via spatially-dependent estimation approaches, which help to reduce the risk of omitted variables. Alternatively, locational variables can be included as controls (Best et al. 2019a).

An alternative to a cross-sectional hedonic estimate is to use a repeated-sales model. This involves examining the average difference in price between two points in time for houses that have a new PV system and those that do not. A drawback is the need for a housing sales dataset covering both before and after solar PV installations. The approach also relies on the assumption that the quality of the homes has not changed over time in a way that is correlated with the decision to install solar panels (Hansen 2009).

The availability of price data from housing sales forms a constraint for hedonic studies. An alternative is to use homeowner estimates of housing values, although these are not fully accurate (Bauer et al. 2011; Doiron and Guttmann 2009; Headey et al. 2005; Marks et al. 2005). Kiel and Zabel (1999) found that the average homeowner in the US overestimates the value of their home by about 5\%. For Australia, Melser (2013) concluded that homeowners overestimated the value of their homes by approximately $2.5 \%$ over $2001-2010$. It is possible that homeowner misestimation may be correlated with factors such as the decision to install solar panels. 
An approach to limit the extent to which homeowner valuation errors influence estimation results is to control for factors that may be correlated with valuation errors, such as socioeconomic and demographic factors. For Australia, Melser (2013) found that the ages of homeowners and size of the household influence the degree of misestimation. Older homeowners were found to provide more modest estimates of their house's value. All else equal, wealthier households (as proxied by the size of their residence) tended to be more likely to overestimate the value of their home.

Socioeconomic controls are often included in hedonic studies in an attempt to account for differences in the purchasing power of households. For instance, income is often included given that higher-income households are likely to be able to better afford various home improvements (Pommeranz and Steininger 2020). We argue that household financial assets are perhaps even more important given they are the stock of liquid resources that can be used for investments (Steegmans and Hassink 2017). We thus introduce financial asset measures into the control set for hedonic models using household datasets from Australia.

\section{Method and data}

\subsection{Model and variables}

We use the following hedonic model:

$\ln D_{h}{ }^{j}=c^{j}+\alpha^{j} S_{h}+\boldsymbol{T}^{\prime}{ }_{h} \boldsymbol{\beta}^{j}+\boldsymbol{L}_{h}{ }_{h} \boldsymbol{\gamma}^{j}+\boldsymbol{H}^{\prime}{ }_{h} \boldsymbol{\lambda}^{j}+\boldsymbol{O}^{\prime}{ }_{h} \boldsymbol{\omega}^{j}+\boldsymbol{A}^{\prime}{ }_{h} \boldsymbol{\theta}^{j}+\boldsymbol{P}^{\prime}{ }_{h} \boldsymbol{\xi}^{j}+\delta^{j} F_{h}+\varepsilon_{h}^{j}$

The dependent variable is the log of the housing value. We use the $j$ superscript to distinguish between regressions for actual and estimated housing prices, carried out separately. We apply this pooled cross-sectional model to large samples of data at the household $(h)$ level.

The explanatory variables include a solar PV variable $(S)$, a vector of location variables $(\boldsymbol{L})$, the $\boldsymbol{T}$ vector which incorporates time effects, a vector of housing attributes $\boldsymbol{H}$, a vector of socio-demographic characteristics $\boldsymbol{O}$, labour force characteristics $\boldsymbol{A}$, population subgroup measures $\boldsymbol{P}$, and financial assets $(F)$. We do not consider the effect of solar thermal installations for water heating. We use the inverse hyperbolic sine (IHS) transformation for the disposable income and financial asset variables to avoid dropping households with zero or negative values for these variables. We progressively add groups of variables and evaluate

the impact of each group. $\varepsilon_{h}^{j}$ is the error term. 
The time vector includes variables for the year of the most recent home purchase, the quarter of the survey interview, and a binary variable to distinguish between the two survey periods. The location vector includes region dummies. There are also variables that measure the logs of median house and attached dwelling values in local areas. Housing attributes include the number of bedrooms and the dwelling type (i.e. stand-alone house, apartment, etc). Sociodemographic characteristics include respondent age, gender, and the highest education level achieved. There is also a variable for the number of people in the household. Further, there are binary variables for family composition and for having a home mortgage.

Labour force variables account for the employment status of the respondent and the household disposable income. Binary variables are also included for each of five population groups relative to an excluded 'other' group. These five groups are employees, entrepreneurs, age pensioners, other government transfer recipients, and self-funded retirees.

\subsection{Data and key relationships}

Most of the variables are drawn from the Survey of Income and Housing of the Australian Bureau of Statistics (ABS) for 2015-16 and 2017-18 (ABS 2017; 2019). These surveys cover different samples of households and are intended to be nationally representative. Households were selected randomly for each survey. The 2015-16 survey covered 17,768 households and the 2017-18 survey covered 14,060 households.

The dependent variables are based on survey questions that ask the respondent to provide an estimated sale price of the dwelling as well as the purchase price for dwellings that were purchased or built in the three years prior (which was approximately $15 \%$ of dwellings). Key explanatory variables are based on the existence of solar systems and their size. We control for median housing price at various Statistical Area (SA) levels from an alternative ABS source (ABS 2018) as an explanatory variable. We use the SA2-median price for stand-alone houses and the SA4-median price for attached dwellings.

We combine the two surveys and control for a survey binary variable. We exclude renters as they were not asked to estimate their housing price value in the surveys. We use the available survey probability weights to weight each household according to how many other households are represented by each household. These household weights are calibrated to be representative of the Australian population, taking into account the state or territory of residence, whether a household is in a capital city, and household composition factors 
including the number of adults and whether there are children in the household. Descriptive statistics are shown in Table 1.

Table 1. Variable descriptions and statistics

\begin{tabular}{|c|c|c|}
\hline Variable & Description & Mean \\
\hline \multicolumn{3}{|l|}{ Dependent } \\
\hline Housing value (est.) & Estimated sale price of dwelling in Australian dollars. & 600,533 \\
\hline Housing value (actual) & $\begin{array}{l}\text { Purchase price for dwellings that were purchased or built } \\
\text { within the three years prior to the survey, in Australian } \\
\text { dollars. These transactions occurred, on average, } 1.5 \text { years } \\
\text { earlier than the estimation of housing prices for the variable } \\
\text { in the row above. }\end{array}$ & 526,114 \\
\hline \multicolumn{3}{|l|}{ Solar } \\
\hline Solar uptake & Solar photovoltaic (PV) panel uptake (yes=1). & 0.24 \\
\hline $\begin{array}{l}\text { Solar uptake, medium } \\
\text { and large systems }\end{array}$ & $\begin{array}{l}\text { Solar photovoltaic (PV) panel uptake greater than } 2.5 \\
\text { kilowatts (yes=1). }\end{array}$ & 0.17 \\
\hline $\begin{array}{l}\text { Solar uptake, large } \\
\text { systems }\end{array}$ & $\begin{array}{l}\text { Solar photovoltaic (PV) panel uptake greater than } 3.5 \\
\text { kilowatts (yes=1). }\end{array}$ & 0.09 \\
\hline \multicolumn{3}{|l|}{ Time } \\
\hline Year purchased dwelling & $\begin{array}{l}\text { The year that the dwelling was purchased. We group years } \\
\text { for regression results into categories: unspecified, before } \\
\text { 1980, 1980-1999, } 2000 \text { or later. The mean relates to the } \\
\text { ungrouped years. }\end{array}$ & 2001 \\
\hline Quarter of survey & The quarter of the survey interview. & 2.6 \\
\hline Wave & $\begin{array}{l}\text { We use a binary variable to distinguish between the two } \\
\text { surveys. The mean refers to either "15" or "17" for } 2015 \text { - } \\
2016 \text { or } 2017-2018 \text { respectively. }\end{array}$ & 15.9 \\
\hline \multicolumn{3}{|l|}{ Location } \\
\hline Region & $\begin{array}{l}\text { There are } 29 \text { regions: four for each of seven states/territories } \\
\text { and one for the Australian Capital Territory. The four } \\
\text { regions within states are major urban, other urban, bounded } \\
\text { locality, and rural balance. }\end{array}$ & $\mathrm{n} / \mathrm{a}$ \\
\hline $\begin{array}{l}\text { Median house price } \\
\text { (SA2) }\end{array}$ & $\begin{array}{l}\text { The median of house prices in a Statistical Area Level } 2 . \\
\text { This is for stand-alone dwellings only. It was for } \\
\text { transactions in 2014, a lagged year to reduce any concerns } \\
\text { over reverse causation. }\end{array}$ & 487,182 \\
\hline $\begin{array}{l}\text { Median price of attached } \\
\text { dwellings (SA4) }\end{array}$ & $\begin{array}{l}\text { The median of attached-dwelling prices in a Statistical Area } \\
\text { Level } 4 \text {. We use SA4 data for attached-housing prices } \\
\text { because more local levels of data produce more missing } \\
\text { values as some small areas have few attached dwellings. It } \\
\text { was for transactions in } 2014 \text {, a lagged year to reduce any } \\
\text { concerns over reverse causation. The results tables refer to } \\
\text { 'unit prices' to save space. }\end{array}$ & 341,000 \\
\hline \multicolumn{3}{|l|}{ Housing attributes } \\
\hline Number of bedrooms & The number of bedrooms in a dwelling. & 3.32 \\
\hline Dwelling type & $\begin{array}{l}\text { Ten categories of dwelling structure including one category } \\
\text { of separate houses, two of semi-detached, four categories of } \\
\text { flats/units/apartments, and three categories listed as "other" } \\
\text { (which include houseboats, for example). }\end{array}$ & $\mathrm{n} / \mathrm{a}$ \\
\hline \multicolumn{3}{|l|}{ Socio-demographic } \\
\hline Age of respondent & $\begin{array}{l}\text { The age of the respondent who answers the survey on } \\
\text { behalf of the household (in years). }\end{array}$ & 57.14 \\
\hline Gender & A binary variable equal to one for male respondents. & 0.59 \\
\hline Education level & $\begin{array}{l}\text { The level of highest educational attainment for the } \\
\text { respondent in } 13 \text { categories from "Year } 8 \text { or below }\end{array}$ & 5.91 \\
\hline
\end{tabular}




\begin{tabular}{|c|c|c|}
\hline & $\begin{array}{l}\text { including never attended school", to "Postgraduate degree". } \\
\text { Seven of the } 13 \text { categories are for types of post-school } \\
\text { qualifications. }\end{array}$ & \\
\hline Family composition & Ten categories of family composition. & $\mathrm{n} / \mathrm{a}$ \\
\hline Number of people & The number of people in a household. & 2.41 \\
\hline Mortgage & $\begin{array}{l}\text { A binary variable equal to one for households who own } \\
\text { their dwelling with a mortgage. }\end{array}$ & 0.51 \\
\hline \multicolumn{3}{|l|}{ Labour force } \\
\hline Employment status & $\begin{array}{l}\text { The labour force status of the household reference person in } \\
\text { three categories (employed/unemployed/not in the labour } \\
\text { force). }\end{array}$ & $\mathrm{n} / \mathrm{a}$ \\
\hline Disposable income & $\begin{array}{l}\text { Disposable income on average per household per week for } \\
\text { the current financial year. }\end{array}$ & $1,702.25$ \\
\hline \multicolumn{3}{|l|}{ Population group } \\
\hline Population group & $\begin{array}{l}\text { Six population groups: employees, entrepreneurs, age } \\
\text { pensioners, other government transfer recipients, self- } \\
\text { funded retirees, and other. }\end{array}$ & $\mathrm{n} / \mathrm{a}$ \\
\hline \multicolumn{3}{|l|}{ Financial assets } \\
\hline Financial assets & The value of total household financial assets. & 510,631 \\
\hline Private pensions & $\begin{array}{l}\text { The total value of superannuation funds at the household } \\
\text { level. In Australia, "superannuation" is the word used to } \\
\text { describe private pension balances. }\end{array}$ & 259,214 \\
\hline $\begin{array}{l}\text { Notes. The sample } \\
\text { transactions in th } \\
\text { (current) sale prices }\end{array}$ & $\begin{array}{l}19,091 \text { except for actual housing values: there were } 2,922 \text { ho } \\
\text { years leading up to the surveys. For these } 2,922 \text { dwellings, th } \\
36,414 \text {, which is just below the average for the full sample. Fr }\end{array}$ & $\begin{array}{l}\text { ds with } \\
\text { mated } \\
\text { details on }\end{array}$ \\
\hline
\end{tabular}

Figure 1 uses APVI (2020) data to show that the size of new small-scale solar installations in Australia has varied considerably over time. Attention in this Figure is limited to systems of up to 9.5 kilowatts as this has been the relevant range for the great majority of household systems to date. Most new small-scale installations were smaller than 2.5 kilowatts as of 2012. The proportion of systems of 6.5-9.5 kilowatts was close to zero. Systems in the 2.54.5 kilowatt range briefly became the most popular for new additions, before systems in the 4.5-6.5 kilowatt range became the most popular during 2015-2018 and then 6.5-9.5 kilowatt systems. At the end of 2016 , around $82 \%$ of all of the systems below 2.5 kilowatts that had been installed had been installed in 2012 or earlier. 
Figure 1. Proportion of monthly new solar installations for four size categories up to 9.5 kilowatts.

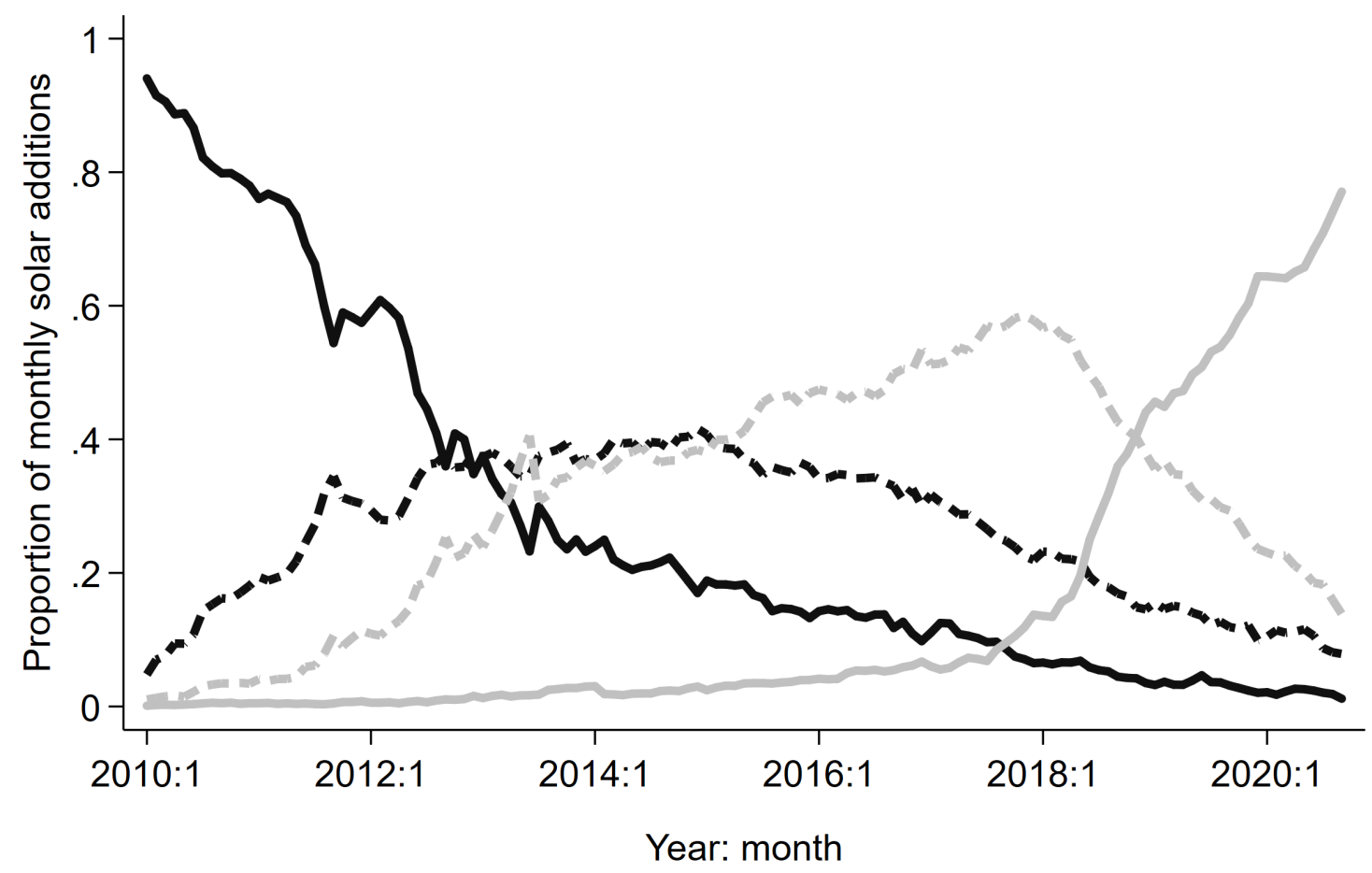

$\longrightarrow<2.5 \mathrm{~kW}-\boldsymbol{-}-2.5<4.5 \mathrm{~kW}=-=4.5<6.5 \mathrm{~kW}=6.5<9.5 \mathrm{~kW}$

Notes: Based on APVI (2020) data.

Figure 2 shows that surveyed households with solar panels have higher estimated and actual housing prices than households without, with a $6 \%$ premium in both cases. This is without considering any controls. It is likely to be an overestimate given that the ability to install solar panels is positively correlated with the ability to invest in other housing attributes.

Figure 2 also reveals that estimates of housing prices are on average $11.5 \%$ higher than actual prices. This is true for both solar and non-solar households. As mentioned, actual prices are based on transactions over the three years prior to the survey. As a result, estimated prices may be higher because respondents are incorporating annual growth into their estimates (of approximately $8 \%$ per year for 1.5 years on average). Estimated sale prices thus appear to be reasonable proxies of actual sale prices (in terms of the overall averages at least). We also control for socio-demographic and economic factors in Section 4 to capture any systematic differences related to other variables. 
Figure 2. Housing values in thousands of Australian dollars.

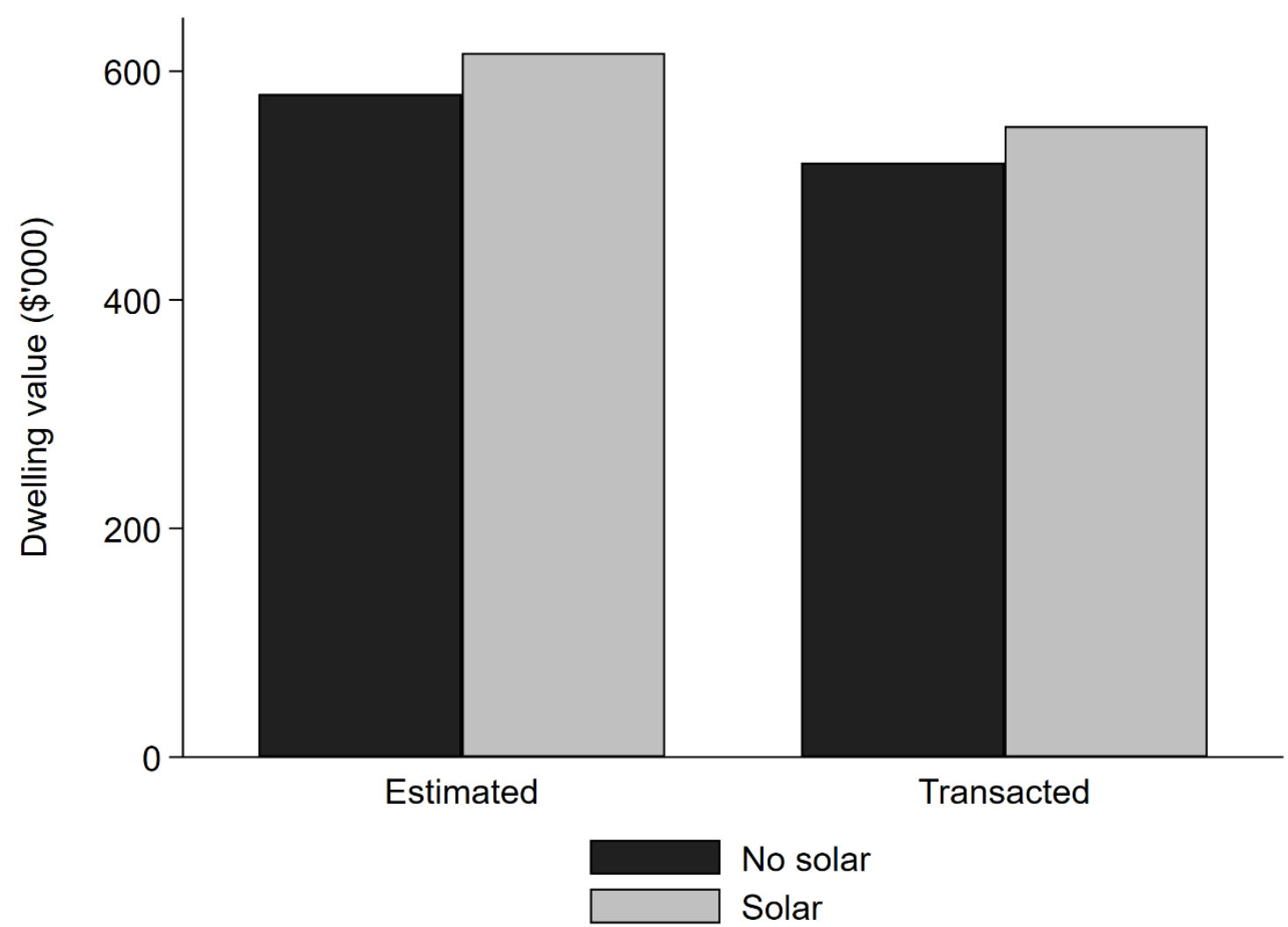

Notes: The left two bars show values estimated by homeowners. The right two bars are actual prices for transactions within three years prior to the survey based on a sample of 2,922 households with data for transacted prices. Based on ABS $(2017 ; 2019)$ data.

Figure 3 shows the association between the size of solar systems and housing values. Housing values are higher for households with large solar systems relative to households without solar systems, but this is not the case for households with small solar systems. Regression results in Section 4 control for other variables such as the number of bedrooms and the financial asset measure.

Figure 3 does not account for efficiency differences in solar panels resulting from degradation in solar system performance over time. Unfortunately, data unavailability means that we are unable to control for the age of household solar PV systems. However smaller systems tend to be older, as suggested by Figure 1. Given that most systems installed in recent years tend to be relatively large, our primary focus will be on the housing price premium for larger systems (i.e. $>2.5$ kilowatts). 
Figure 3. Solar capacity and the estimated dwelling sale price in thousands of Australian dollars.

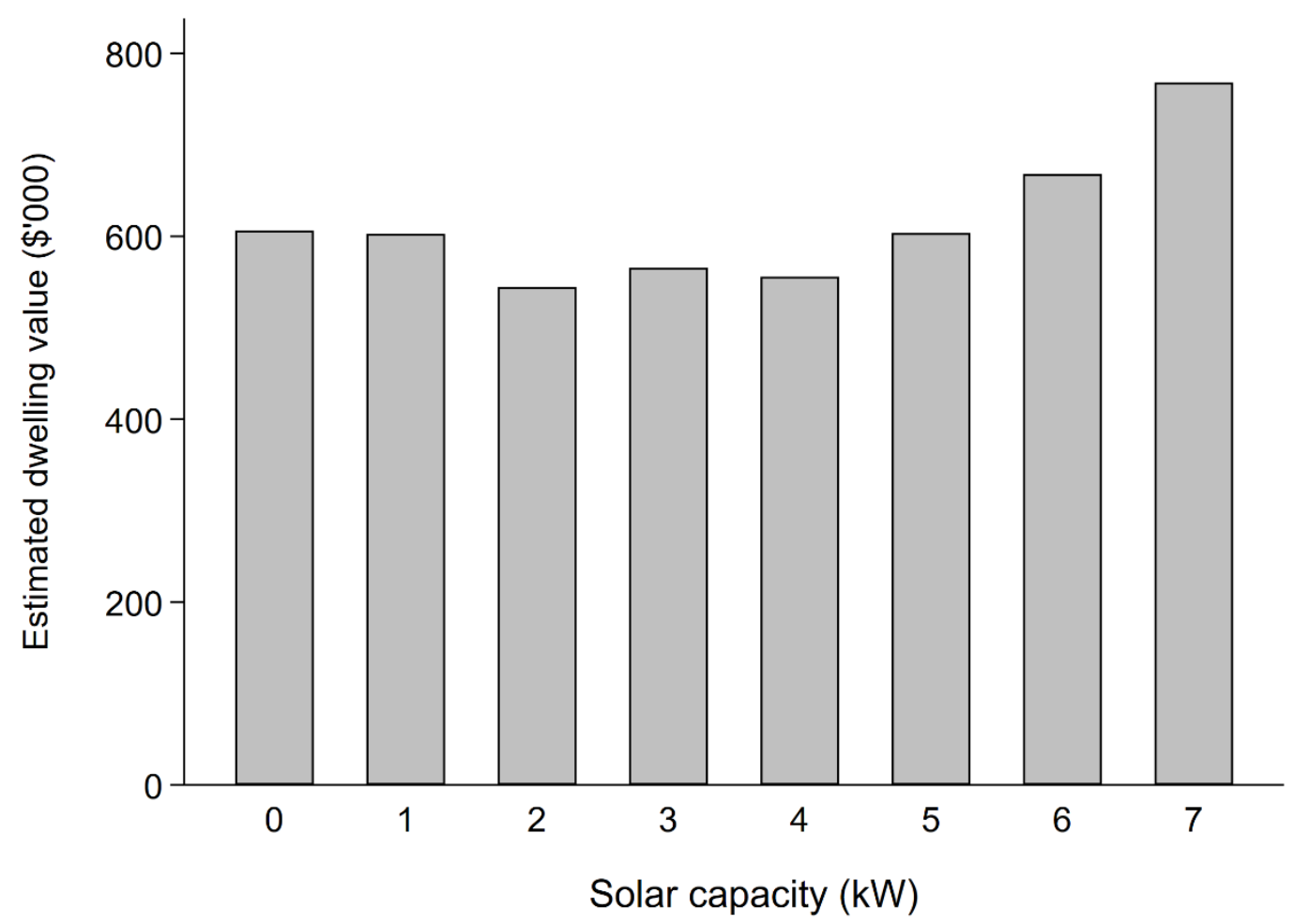

Notes: Solar capacity is rounded up to the nearest integer. The final category of ' 7 ' includes all systems above 7 kilowatts. Based on the sample of 19,091 households. Source: based on ABS $(2017 ; 2019)$ data.

\subsection{Hierarchical and location variables}

Each regression controls for the locational region via the use of binary variables. Australia has eight states/territories. Other than the Australian Capital Territory, each is divided into four regions. This gives a total of 29 regions.

We control for median housing values at the local level for stand-alone houses and attached dwellings, which is a relatively concise way to capture unobserved locational effects. We use the SA2 median for stand-alone housing. SA2 areas on average contain approximately 5,000 households. For attached dwellings, we use the SA4 level, which generally covers over 100,000 households (because finer scales of aggregation result in problems with missing values). Both variables use 2014 transaction data. Use of data for an earlier year helps to reduce concerns over reverse causation from a single housing price to the area median.

\subsection{Financial assets}

Financial assets are assets held with financial institutions, shares, trusts, silent partnerships, bonds, the net value of businesses, superannuation funds, loans to persons not in the same 
household, and other financial investments. Liabilities such as mortgages are not deducted from the financial asset variable.

Including a financial asset control is a way of seeking to indirectly control for other housing attributes that may be relevant for housing values, as households with larger financial asset balances would be able to afford to live in housing with superior attributes. Without such a control, one may overestimate the relevance of any one positive housing attribute on housing prices.

Figure 4 shows the substantial difference in the financial assets of solar and non-solar households. Financial assets are approximately 18\% higher for households with solar panels compared to those without. Private pension balances for households with solar panels are around 32\% higher. These differences are consistent with prior studies that find that wealthier households are more likely to install a solar system (Best et al. 2019b; Best and Trück 2020).

Figure 4. Asset values in thousands of Australian dollars.

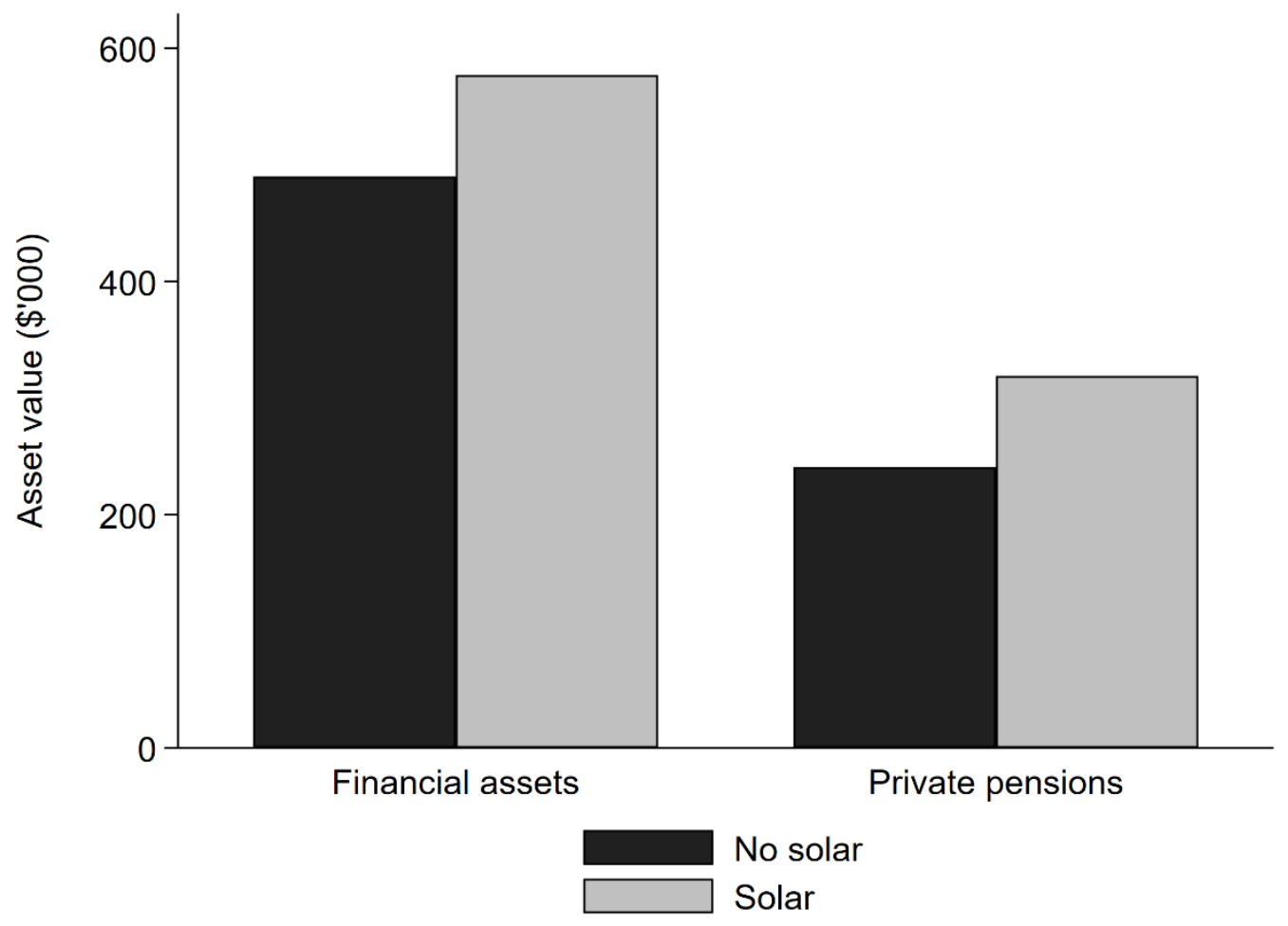

Notes: The left two bars show values for financial assets. The right two bars are for private pension balances (known as superannuation balances in Australia). The values are based on the sample of 19,091 households. Source: based on ABS $(2017 ; 2019)$ data.

A downside of including a financial asset control is the risk of reverse causation. Those who spend more on houses (including solar installations) have less available for saving in liquid 
assets, as different assets are substitutes within a given total wealth portfolio. It is also possible that a third variable, such as wealth-generating ability, is correlated with both financial assets and the value of the primary residence. Controlling for other variables such as income and education lowers this risk.

We also describe robustness tests that use private pension account balances instead of financial assets. The compulsory nature of superannuation in Australia means that this variable is less affected by decisions to invest in housing than it would otherwise be, noting that only a minority of households make voluntary top-up contributions to their superannuation accounts. We mention a robustness test in Section 4 that only includes households for which the respondent was below 50 years of age, as younger respondents are especially unlikely to make voluntary contributions to their private pensions given that retirement is more distant.

The calculation of financial assets may involve measurement error, however an ameliorating factor is that survey respondents are not required to do the addition across financial asset components themselves. Instead, the ABS does an addition based on 12 separate financial asset questions.

\section{Results}

Column (1) of Table 2 reports a positive and significant coefficient for the binary solar variable in explaining the log of estimated housing prices in an estimation that only includes a limited control set. Column (2) controls for the log of the median local housing price measures, increasing the explained variation substantially. The binary solar coefficient increases to just below the initial association identified in Figure 2. Column (3) uses probability weights, which reduces the solar coefficient. In column (4) we also control for the disposable income variable (constructed using the IHS transformation). The solar coefficient does not change substantially.

Column (5) of Table 2 adds the financial assets variable, expressed using the IHS transformation. The solar coefficient declines substantially and switches to being statistically insignificant. Robustness tests using private pension balances instead of financial assets also lead to a lower point estimate for the solar coefficient, including when restricting the sample to respondents under the age of 50. The insignificant point estimate of 0.01 is still relatively large when it is considered that housing prices in Australia are quite high. $1 \%$ of the median 
housing value of approximately A $\$ 600,000$ in Figure 1 corresponds to approximately A $\$ 6,000$.

Table 2. Results explaining the log of estimated housing prices

\begin{tabular}{lrrrrr}
\hline & $(1)$ & $(2)$ & $(3)$ & $(4)$ & $(5)$ \\
\hline Solar panels, binary & $0.036^{* * *}$ & $0.054^{* * *}$ & $0.032^{* * *}$ & $0.030^{* * *}$ & 0.013 \\
& $(0.009)$ & $(0.007)$ & $(0.009)$ & $(0.009)$ & $(0.009)$ \\
Number of bedrooms & $0.225^{* * *}$ & $0.191^{* * *}$ & $0.185^{* * *}$ & $0.177^{* * *}$ & $0.164^{* * *}$ \\
& $(0.006)$ & $(0.005)$ & $(0.008)$ & $(0.008)$ & $(0.008)$ \\
Log house price (SA2) & & $0.845^{* * *}$ & $0.863^{* * *}$ & $0.851^{* * *}$ & $0.804^{* * *}$ \\
& & $(0.012)$ & $(0.015)$ & $(0.015)$ & $(0.015)$ \\
Log unit price (SA4) & & $0.102^{* * *}$ & $0.113^{* * *}$ & $0.107^{* * *}$ & $0.128^{* * *}$ \\
& & $(0.020)$ & $(0.025)$ & $(0.025)$ & $(0.024)$ \\
Disposable income (IHS) & & & & $0.039^{* * *}$ & \\
& & & & $(0.005)$ & \\
Financial assets (IHS) & & & & & $0.051^{* * *}$ \\
& & & & & $(0.003)$ \\
Other attributes & Yes & Yes & Yes & Yes & Yes \\
Location & Yes & Yes & Yes & Yes & Yes \\
Time & Yes & Yes & Yes & Yes & Yes \\
Housing & No & No & Yes & Yes & Yes \\
Probability weights & 0.385 & 0.632 & 0.647 & 0.652 & 0.669 \\
$R^{2}$ & & & & \\
\hline
\end{tabular}

Notes. ${ }^{* *}, * *, *$ show statistical significance at 1,5 and 10 per cent levels respectively. Robust standard errors are in parentheses below the coefficients. The sample size is 19,091 in each column. IHS=inverse hyperbolic sine.

In Table 3 we focus on potential impacts of medium and large solar systems, which have become more popular in recent years. Solar PV systems larger than 2.5 kilowatts have a positive and significant effect at the $1 \%$ level up to column (5), with the magnitudes of the solar coefficients declining from column (2) to column (6). As can be seen in column (5), the inclusion of the financial assets control reduces the size of the solar coefficient. It remains positive and significant at the $1 \%$ level. Column (6) adds the full set of controls including socio-demographic, labour force, and population groups, leading to a further decline in the point estimate of the solar coefficient.

In Table 4 we focus on potential impacts of relatively large solar systems, using a solar binary variable that equals one only for households with solar systems of above 3.5 kilowatts. A similar pattern is observed: the point estimate of the solar coefficient tends to decline as more controls are added, and including the financial asset control in column (5) has a substantial impact in reducing the point estimate for the solar PV coefficient. Having a solar system larger than 3.5 kilowatts is associated with an approximately $4 \%$ higher estimated housing value, all else equal. This is a large effect. 
Table 3. Results using medium and large solar systems $(>2.5 \mathrm{~kW})$ to explain the log of estimated housing values

\begin{tabular}{lrrrrrr}
\hline & $(1)$ & $(2)$ & $(3)$ & $(4)$ & $(5)$ & $(6)$ \\
\hline Solar panels, >2.5kW & $0.046^{* * *}$ & $0.073^{* * *}$ & $0.054^{* * *}$ & $0.052^{* * *}$ & $0.035^{* * *}$ & $0.019^{* *}$ \\
& $(0.010)$ & $(0.008)$ & $(0.010)$ & $(0.010)$ & $(0.010)$ & $(0.010)$ \\
Number of bedrooms & $0.225^{* * *}$ & $0.190^{* * *}$ & $0.185^{* * *}$ & $0.176^{* * *}$ & $0.163^{* * *}$ & $0.150^{* * *}$ \\
& $(0.006)$ & $(0.005)$ & $(0.008)$ & $(0.008)$ & $(0.008)$ & $(0.008)$ \\
Log house price (SA2) & & $0.846^{* * *}$ & $0.864^{* * *}$ & $0.852^{* * *}$ & $0.805^{* * *}$ & $0.773^{* * *}$ \\
& & $(0.012)$ & $(0.015)$ & $(0.015)$ & $(0.015)$ & $(0.015)$ \\
Log unit price (SA4) & & $0.103^{* * *}$ & $0.113^{* * *}$ & $0.107^{* * *}$ & $0.128^{* * *}$ & $0.141^{* * *}$ \\
& & $(0.020)$ & $(0.025)$ & $(0.025)$ & $(0.024)$ & $(0.024)$ \\
Disposable income (IHS) & & & & $0.039^{* * *}$ & & $0.020^{* * *}$ \\
& & & & $(0.005)$ & & $(0.005)$ \\
Financial assets (IHS) & & & & & $0.050^{* * *}$ & $0.036^{* * *}$ \\
& & & & & $(0.003)$ & $(0.003)$ \\
Other attributes & & & & & & \\
Location & Yes & Yes & Yes & Yes & Yes & Yes \\
Time & Yes & Yes & Yes & Yes & Yes & Yes \\
Housing & Yes & Yes & Yes & Yes & Yes & Yes \\
Socio-demographic & No & No & No & No & No & Yes \\
Labour force & No & No & No & No & No & Yes \\
Population group & No & No & No & No & No & Yes \\
Probability weights & No & No & Yes & Yes & Yes & Yes \\
$R^{2}$ & 0.385 & 0.633 & 0.648 & 0.652 & 0.670 & 0.685 \\
\hline
\end{tabular}

Notes. ${ }^{* *},{ }^{* *}, *$ show statistical significance at 1,5 and 10 per cent levels respectively. Robust standard errors are in parentheses below the coefficients. The sample size is 19,091 in each column. IHS=inverse hyperbolic sine.

The controls in Table 4 produce expected coefficient signs. There is a positive coefficient for the number of bedrooms. The log housing price in the SA2 area has a positive coefficient, with a $p$-value close to zero. The coefficient for income is approximately 0.04 in column (4), although this drops to 0.02 in column (6) when controlling for other variables. The average variance inflation factor is 1.6 , suggesting that multicollinearity is not a pressing concern. The highest variance inflation factors of up to 5.0 - for the median local housing price and labour force status variables - are still below the common threshold of 10 .

The smaller and insignificant coefficient for the binary solar variable in Table 2 but larger and significant coefficient for the binary variable for larger solar systems may be reflecting several phenomena. First, small systems may truly not contribute much to house prices. Second, small systems tend to be older and thus subject to greater physical degradation. Third, households with older systems also have reduced ability to install new capacity given the reduction in their available roof space. Fourth, having a small solar PV system may be correlated with factors such as unusual roof shape or small roof size that we have not been able to adequately control for because they were not measured in the survey. We have controlled for the number of bedrooms and the dwelling type. 
Table 4. Results using large solar systems $(>3.5 \mathrm{~kW})$ to explain the log of estimated housing values

\begin{tabular}{lrrrrrr}
\hline & $(1)$ & $(2)$ & $(3)$ & $(4)$ & $(5)$ & $(6)$ \\
\hline Solar panels, >3.5kW & $0.077^{* * *}$ & $0.100^{* * *}$ & $0.081^{* * *}$ & $0.076^{* * *}$ & $0.055^{* * *}$ & $0.042^{* * *}$ \\
& $(0.013)$ & $(0.010)$ & $(0.013)$ & $(0.013)$ & $(0.013)$ & $(0.012)$ \\
Number of bedrooms & $0.224^{* * *}$ & $0.189^{* * *}$ & $0.184^{* * *}$ & $0.175^{* * *}$ & $0.162^{* * *}$ & $0.150^{* * *}$ \\
& $(0.006)$ & $(0.005)$ & $(0.008)$ & $(0.008)$ & $(0.008)$ & $(0.008)$ \\
Log house price (SA2) & & $0.845^{* * *}$ & $0.864^{* * *}$ & $0.852^{* * *}$ & $0.805^{* * *}$ & $0.773^{* * *}$ \\
& & $(0.012)$ & $(0.015)$ & $(0.015)$ & $(0.015)$ & $(0.015)$ \\
Log unit price (SA4) & & $0.102^{* * *}$ & $0.114^{* * *}$ & $0.108^{* * *}$ & $0.128^{* * *}$ & $0.142^{* * *}$ \\
& & $(0.020)$ & $(0.025)$ & $(0.025)$ & $(0.024)$ & $(0.024)$ \\
Disposable income (IHS) & & & & $0.038^{* * *}$ & & $0.020^{* * *}$ \\
& & & & $(0.005)$ & & $(0.005)$ \\
Financial assets (IHS) & & & & & $0.050^{* * *}$ & $0.036^{* * *}$ \\
& & & & & $(0.003)$ & $(0.003)$ \\
Other attributes & & & & & & \\
Location & Yes & Yes & Yes & Yes & Yes & Yes \\
Time & Yes & Yes & Yes & Yes & Yes & Yes \\
Housing & Yes & Yes & Yes & Yes & Yes & Yes \\
Socio-demographic & No & No & No & No & No & Yes \\
Labour force & No & No & No & No & No & Yes \\
Population group & No & No & No & No & No & Yes \\
Probability weights & No & No & Yes & Yes & Yes & Yes \\
$R^{2}$ & 0.386 & 0.633 & 0.648 & 0.652 & 0.670 & 0.685 \\
\hline
\end{tabular}

Notes. ${ }^{* * *}, * * *$ show statistical significance at 1,5 and 10 per cent levels respectively. Robust standard errors are in parentheses below the coefficients. The sample size is 19,091 in each column. IHS=inverse hyperbolic sine.

Table 5 uses continuous measures of solar PV capacity. Column (1) uses the IHS transformation of the solar capacity variable along with the full control set from column (6) of Table 3 and 4, except for the financial asset variable. A positive and significant coefficient at the $10 \%$ level of 0.008 is obtained for the solar capacity variable. When controlling for the financial asset variable (which also uses the IHS transformation) in column (2), the solar variable has a magnitude of 0.004 , which is insignificantly different to zero.

Column (3) of Table 5 is the same as column (2) except that solar capacity is coded as zero for solar systems smaller than or equal to 2.5 kilowatts given that some old and small systems may have low electricity output and not add much to housing values. The solar coefficient is positive and significant at the $5 \%$ level. Column (4) finds a positive and significant impact of log solar capacity without the IHS transformation for a sample of residences with solar panels. A solar-capacity elasticity of (estimated) housing prices of 0.09 is obtained. For residences with panels, a 1\% increase in solar capacity is therefore on average associated with a $0.09 \%$ increase in estimated housing prices. Column (5) also shows a positive and significant impact of the log of solar capacity (using the IHS transformation) on the log of actual (rather than estimated) housing prices. 
Table 5. Results explaining estimated or actual (transacted) housing prices

\begin{tabular}{|c|c|c|c|c|c|}
\hline $\begin{array}{r}\text { Log of house price that } \\
\text { is: }\end{array}$ & $\begin{array}{r}\text { (1) } \\
\text { Estimated }\end{array}$ & $\begin{array}{r}(2) \\
\text { Estimated }\end{array}$ & $\begin{array}{r}(3) \\
\text { Estimated }\end{array}$ & $\begin{array}{r}\text { (4) } \\
\text { Estimated }\end{array}$ & $\begin{array}{r}(5) \\
\text { Actual }\end{array}$ \\
\hline Solar capacity (IHS) & $\begin{array}{l}0.008^{*} \\
(0.004)\end{array}$ & $\begin{array}{r}0.004 \\
(0.004)\end{array}$ & $\begin{array}{r}0.011 * * \\
(0.004)\end{array}$ & & $\begin{array}{r}0.023 * * \\
(0.009)\end{array}$ \\
\hline Log solar capacity & & & & $\begin{array}{r}0.093 * * * \\
(0.014)\end{array}$ & \\
\hline Number of bedrooms & $\begin{array}{r}0.156^{* * *} \\
(0.009)\end{array}$ & $\begin{array}{r}0.150 * * * \\
(0.008)\end{array}$ & $\begin{array}{r}0.150 * * * \\
(0.008)\end{array}$ & $\begin{array}{r}0.110^{* * *} \\
(0.010)\end{array}$ & $\begin{array}{r}0.132 * * * \\
(0.014)\end{array}$ \\
\hline Log house price (SA2) & $\begin{array}{r}0.791 * * * \\
(0.015)\end{array}$ & $\begin{array}{r}0.773 * * * \\
(0.015)\end{array}$ & $\begin{array}{r}0.773 * * * \\
(0.015)\end{array}$ & $\begin{array}{r}0.811^{* * * *} \\
(0.029)\end{array}$ & $\begin{array}{r}0.726^{* * *} \\
(0.034)\end{array}$ \\
\hline Log unit price (SA4) & $\begin{array}{r}0.132 * * * \\
(0.024)\end{array}$ & $\begin{array}{r}0.141 * * * \\
(0.024)\end{array}$ & $\begin{array}{r}0.141^{* * *} \\
(0.024)\end{array}$ & $\begin{array}{r}0.076 \\
(0.046)\end{array}$ & $\begin{array}{r}0.117 * * \\
(0.052)\end{array}$ \\
\hline Disposable income (IHS) & $\begin{array}{r}0.032 * * * \\
(0.005)\end{array}$ & $\begin{array}{r}0.020 * * * \\
(0.005)\end{array}$ & $\begin{array}{r}0.020 * * * \\
(0.005)\end{array}$ & $\begin{array}{r}0.013 \\
(0.010)\end{array}$ & $\begin{array}{r}0.012 \\
(0.007)\end{array}$ \\
\hline Financial assets (IHS) & & $\begin{array}{r}0.036^{* * *} \\
(0.003)\end{array}$ & $\begin{array}{r}0.036^{* * *} \\
(0.003)\end{array}$ & $\begin{array}{r}0.040^{* * *} \\
(0.005)\end{array}$ & $\begin{array}{r}0.046^{* * *} \\
(0.008)\end{array}$ \\
\hline Other attributes & Yes & Yes & Yes & Yes & Yes \\
\hline Observations & 19,091 & 19,091 & 19,091 & 4,528 & 2,922 \\
\hline$R^{2}$ & 0.677 & 0.684 & 0.685 & 0.642 & 0.702 \\
\hline
\end{tabular}

Notes. $* * *, * *, *$ show statistical significance at 1,5 and 10 per cent levels respectively. Robust standard errors are in parentheses below the coefficients. Each column uses probability weights and the full set of controls (other than column (1) which does not control for financial assets). Column (3) has solar capacity coded as zero for systems that are less than or equal to 2.5 kilowatts. IHS=inverse hyperbolic sine.

\section{Conclusion and implications}

This study has investigated the impact of solar panels on housing prices in Australia using a control set that includes key locational, economic, and financial variables. We found that controlling for financial assets appears to be a useful approach in estimating the housing price premium from solar installations. There is a more noticeable solar premium for larger installations, as expected. Solar PV systems of over 3.5 kilowatts are found to be associated with a housing price premium of around $4 \%$.

The results have implications for the design of current and future government policies and schemes. Multiple government schemes in Australia have, in effect, subsidised rooftop solar. The early phase of solar support included state-level feed-in tariffs and the national Smallscale Renewable Energy Scheme (SRES). Both the benefits and the costs of solar adoption have tended to favour better-off households (Nelson et al. 2011; 2012; Best et al. 2021). The estimates in this paper show that the net benefits of having rooftop solar have tended to flow through to higher housing prices for solar homes. The magnitude of the effect is quite large.

Future studies might further explore solar policies that help to reduce rather than exacerbate inequality. One approach is for solar installation subsidies to be capped for larger systems. For example, a maximum solar panel rebate of $\mathrm{A} \$ 1,850$ applies for homeowners and rental 
properties in the state of Victoria (Solar Victoria 2020). This contrasts to the SRES where subsidies are proportional to capacity and uncapped up to 100 kilowatts. Another option would be use of a gradual subsidy tailoring approach as a function of system size.

Solar policies could also be increasingly targeted towards disadvantaged groups, such as electricity consumers experiencing hardship (ACCC 2020). Renters are also a priority group, with a scheme in Victoria already targeting solar for rental properties (Solar Victoria 2020). Changes to tenancy laws may also help to facilitate greater solar uptake on rental properties (Nelson et al. 2019).

The approach of controlling for financial assets, or some alternative that captures financial capacity differences across households, is relevant for future hedonic studies seeking to estimate the price premia associated with home attributes. For example, the premium from having a home water tank could be estimated using this approach. Future studies may also be able to examine other aspects of the price premium for solar PV installations, such as the effects of system age and output.

Data are a constraining factor in studies such as this. Future research may be able to utilise data on solar system installation dates if they are available so as to examine how the solar home price premium evolves as a function of system age. If available, data on the electricity output from each household's solar panels would also be of use for understanding effects of solar system size on housing prices. 


\section{References}

ABS. (2017). Australian Bureau of Statistics. 2015-16 Survey of Income and Housing, Detailed Microdata, Datalab. Findings based on use of ABS Microdata.

ABS. (2018). Australian Bureau of Statistics. Data by Region. https://www.abs.gov.au/ausstats/abs@.nsf/mf/1410.0.

ABS. (2019). Australian Bureau of Statistics. 2017-18 Survey of Income and Housing, Detailed Microdata, Datalab. Findings based on use of ABS Microdata.

Abelson, P., Joyeux, R., and Mahuteau, S. (2013). Modelling house prices across Sydney. Australian Economic Review, 46(3), 269-285. https://doi.org/10.1111/j.14678462.2013.12013.x

ACCC. (2018). Restoring electricity affordability and Australia's competitive advantage, (June). Australian Competition and Consumer Commission.

ACCC. (2020). Inquiry into the National Electricity Market. September 2020 Report. Australian Competition and Consumer Commission.

Andreoni, J. (1990). Impure Altruism and Donations to Public Goods: A Theory of WarmGlow Giving. The Economic Journal, 100(401), 464-477.

APVI, 2020. Mapping Australian Photovoltaic installations. Australian PV Institute. https://pv-map.apvi.org.au/historical (accessed 25.8.20).

Bauer, T. K., Cobb-Clark, D. A., Hildebrand, V. A., and Sinning, M. G. (2011). A comparative analysis of the nativity wealth gap. Economic Inquiry, 49(4), 989-1007. https://doi.org/10.1111/j.1465-7295.2009.00221.x

Best, R., and Burke, P. J. (2019). Factors contributing to energy-related financial stress in Australia. Economic Record, 95(311), 462-479. https://doi.org/10.1111/14754932.12504

Best, R., Burke, P. J., and Nishitateno, S. (2019a). Evaluating the effectiveness of Australia's small-scale renewable energy scheme for rooftop solar. Energy Economics, 104475. https://doi.org/10.1016/j.eneco.2019.104475

Best, R., Burke, P. J., and Nishitateno, S. (2019b). Understanding the determinants of rooftop solar installation: evidence from household surveys in Australia. Australian Journal of Agricultural and Resource Economics, 63(4), 922-939. https://doi.org/10.1111/14678489.12319

Best, R., and Trück, S. (2020). Capital and policy impacts on Australian small-scale solar installations. Energy Policy, 136 (November 2019), 111082. https://doi.org/10.1016/j.enpol.2019.111082

Best, R., Chareunsy, A., Li, H. (2021). Equity and effectiveness of Australian small-scale solar schemes. Ecological Economics. 180, 106890. https://doi.org/10.1016/j.ecolecon.2020.106890

Bond, S. A., and Devine, A. (2016). Incentivizing Green Single-Family Construction: Identifying Effective Government Policies and Their Features. Journal of Real Estate Finance and Economics, 52(4), 383-407. https://doi.org/10.1007/s11146-015-9525-0

Brounen, D., and Kok, N. (2011). On the economics of energy labels in the housing market. Journal of Environmental Economics and Management, 62(2), 166-179. 
https://doi.org/10.1016/j.jeem.2010.11.006

Chegut, A., Eichholtz, P., Holtermans, R., and Palacios, J. (2020). Energy Efficiency Information and Valuation Practices in Rental Housing. Journal of Real Estate Finance and Economics, 60(1-2), 181-204. https://doi.org/10.1007/s11146-019-09720-0

Dastrup, S. R., Graff Zivin, J., Costa, D. L., and Kahn, M. E. (2012). Understanding the Solar Home price premium: Electricity generation and "Green" social status. European Economic Review, 56(5), 961-973. https://doi.org/10.1016/j.euroecorev.2012.02.006

Deng, Y., Li, Z., and Quigley, J. M. (2012). Economic returns to energy-efficient investments in the housing market: Evidence from Singapore. Regional Science and Urban Economics, 42(3), 506-515. https://doi.org/10.1016/j.regsciurbeco.2011.04.004

Doiron, D., and Guttmann, R. (2009). Wealth distributions of migrant and Australian-born households. Economic Record, 85(268), 32-45. https://doi.org/10.1111/j.14754932.2008.00527.x

Eichholtz, P., Kok, N., and Quigley, J. M. (2010). Doing Well by Doing Good ? Green Office Buildings. American Economic Review, 100(5), 2492-2509.

Fuerst, F., and Warren-Myers, G. (2018). Does voluntary disclosure create a green lemon problem? Energy-efficiency ratings and house prices. Energy Economics, 74, 1-12. https://doi.org/10.1016/j.eneco.2018.04.041

Hansen, J. (2009). Australian house prices: A comparison of hedonic and repeat-sales measures. Economic Record, 85(269), 132-145. https://doi.org/10.1111/j.14754932.2009.00544.x

Headey, B., Marks, G., and Wooden, M. (2005). The structure and distribution of household wealth in Australia. Australian Economic Review, 38(2), 159-175. https://doi.org/10.1111/j.1467-8462.2005.00363.x

Hoen, B., Wiser, R., Thayer, M., and Cappers, P. (2013). Residential photovoltaic energy systems in California: The effect on home sales prices. Contemporary Economic Policy, 31(4), 708-718. https://doi.org/10.1111/j.1465-7287.2012.00340.x

Holtermans, R., and Kok, N. (2019). On the Value of Environmental Certification in the Commercial Real Estate Market. Real Estate Economics, 47(3), 685-722. https://doi.org/10.1111/1540-6229.12223

IEA, 2020. IEA PVPS report - Trends in Photovoltaic Applications 2020. International Energy Agency.

Kahn, M. E., and Kok, N. (2014). The capitalization of green labels in the California housing market. Regional Science and Urban Economics, 47(1), 25-34. https://doi.org/10.1016/j.regsciurbeco.2013.07.001

Kiel, K. A., and Zabel, J. E. (1999). The accuracy of owner-provided house values: the 19781991 American Housing Survey. Real Estate Economics, 27(2), 263-298.

Lan, H., Gou, Z. and Yang, L. (2020) House price premium associated with residential solar photovoltaics and the effect from feed-in tariffs: A case study of Southport in Queensland, Australia. Renewable Energy 161, 907-916. doi: 10.1016/j.renene.2020.07.085.

Ma, C., Burton, M. (2016). Warm glow from green power: Evidence from Australian electricity consumers. Journal of Environmental Economics and Management 78, 106120. https://doi.org/10.1016/j.jeem.2016.03.003 
Ma, C., Polyakov, M., and Pandit, R. (2016). Capitalisation of residential solar photovoltaic systems in Western Australia. Australian Journal of Agricultural and Resource Economics, 60(3), 366-385. https://doi.org/10.1111/1467-8489.12126

Marks, G. N., Headey, B., and Wooden, M. (2005). Household wealth in Australia: Its components, distribution and correlates. Journal of Sociology, 41(1), 47-68. https://doi.org/10.1177/1440783305050963

Melser, D. (2013). How Well Do Australian Home-Owners Know the Value of Their Home? Australian Economic Review, 46(1), 31-44. https://doi.org/10.1111/j.14678462.2013.00715.x

Nelson, T., Simshauser, P., Kelley, S. (2011). Australian Residential Solar Feed-in Tariffs: Industry Stimulus or Regressive form of Taxation? Economic Analysis \& Policy 41, 113-129. https://doi.org/10.1016/S0313-5926(11)50015-3

Nelson, T., Simshauser, P., Nelson, J. (2012). Queensland Solar Feed-In Tariffs and the Merit-Order Effect: Economic Benefit, or Regressive Taxation and Wealth Transfers? Economic Analysis \& Policy 42, 277-301. https://doi.org/10.1016/S03135926(12)50030-5

Nelson, T., McCracken-Hewson, E., Sundstrom, G., Hawthorne, M. (2019). The drivers of energy-related financial hardship in Australia - understanding the role of income, consumption and housing. Energy Policy 124, 262-271. https://doi.org/10.1016/j.enpol.2018.10.003

Pommeranz, C., and Steininger, B. I. (2020). What Drives the Premium for Energy-Efficient Apartments - Green Awareness or Purchasing Power? Journal of Real Estate Finance and Economics. https://doi.org/10.1007/s11146-020-09755-8

Qiu, Y., Wang, Y. D., and Wang, J. (2017). Soak up the sun: Impact of solar energy systems on residential home values in Arizona. Energy Economics, 66, 328-336. https://doi.org/10.1016/j.eneco.2017.07.001

Shen, X., Liu, P., Qiu, Y., Patwardhan, A., and Vaishnav, P. (2020). Estimation of change in house sales prices in the United States after heat pump adoption. Nature Energy. https://doi.org/10.1038/s41560-020-00706-4

Solar Victoria. (2020). Welcome to the Solar Homes Program. https://www.solar.vic.gov.au/ Steegmans, J., and Hassink, W. (2017). Financial position and house price determination: An empirical study of income and wealth effects. Journal of Housing Economics, 36, 8-24. https://doi.org/10.1016/j.jhe.2017.02.004

Walls, M., Gerarden, T., Palmer, K., and Bak, X. F. (2017). Is energy efficiency capitalized into home prices? Evidence from three U.S. cities. Journal of Environmental Economics and Management, 82, 104-124. https://doi.org/10.1016/j.jeem.2016.11.006

Wilhelmsson, M. (2000). The impact of traffic noise on the values of single-family houses. Journal of Environmental Planning and Management, 43(6), 799-815. https://doi.org/10.1080/09640560020001692

Yoshida, J., and Sugiura, A. (2015). The Effects of Multiple Green Factors on Condominium Prices. Journal of Real Estate Finance and Economics, 50(3), 412-437. https://doi.org/10.1007/s11146-014-9462-3

Zhang, L., Wu, J., Liu, H., and Zhang, X. (2020). The Value of Going Green in the Hotel Industry: Evidence from Beijing. Real Estate Economics, 48(1), 174-199. 